\title{
Constitutionalism Concept in Implementation of Indonesian State Administration
}

\author{
Adhe Ismail Ananda*) \\ *) Institut Agama Islam Al Mawadah Warrahmah, Kolaka, Southeast Celebes, E- \\ mail: adheismy104@gmail.com
}

\begin{abstract}
The study in writing this paper is the essence of understanding constitutionalism in the context of the administration of the constitutional system. Constitutionalism for modern countries is a necessity. In the understanding of constitutionalism, the constitution is the embodiment of the highest law that must be obeyed by all components of the state. Writing the paper aims to explore further the philosophical meaning of this understanding of Constitutionalism. That in the concept and understanding of Constitutionalism, there are three things that become its essence. First, there is a limitation of power. Second, the exercise of power is carried out based on a general agreement that is crystallized into the constitution, and Third, the exercise of power always requires accountability within the framework of the constitution.
\end{abstract}

Keywords: Constitutionalism; Constitutional System; Administration Power.

\section{Introduction}

For modern countries, the desire to effectively guarantee the political rights of citizens and regulate the orderly administration of state power has encouraged every country to adopt constitutionalism. It is believed that the best way for this purpose is with a constitution, so that constitutionalism for modern countries is a necessity. The necessity for modern countries to embrace constitutionalism is based on the understanding that the constitution is considered the embodiment of the highest law that must be obeyed by the state and even government officials, in accordance with the argument put forward by John Adams government by law, not by men. ${ }^{1}$ The constitution also guarantees the existence of political rights and provides for the distribution of state power in such a way that executive power is balanced by the powers of parliament and legal institutions. ${ }^{2}$ Constitutional laws and regulations regulate the state in terms of its organization. In other words, constitutional law regulations are legal regulations that regulate and determine the state organization of a country. There are two forms of constitutional law regulations, namely constitutional law regulations in the form of written regulations and unwritten regulations. ${ }^{3}$

In fact, constitutionalism is a very old understanding, which existed before the birth of the idea of constitution. It is proven that constitutionalism has become a role model since the government of the ancient Greek polis/state, the Ancient Roman era, and the history of the Islamic caliphate, as revealed in the Medina Charter. Simply put,

\footnotetext{
${ }^{1}$ Richard Samuelson. (2003). John Adams and the Republic of Law. Maryland: Lexington Books, p. 118. ${ }^{2}$ Miriam Budiardjo. (2008). "Dasar-Dasar Ilmu Politik, Edisi Revisi". Jakarta: Gramedia Pustaka Utama, p. 112.

${ }^{3}$ Evy Yuliati and Widayati, "Public Services in Election of Regional Chairman", in Law Development Journal Vol 3 No 1, http://jurnal.unissula.ac.id/index.php/ldj/article/view/14233, p. 22.
} 
constitutionalism is presented with the aim of keeping the government running in an orderly manner. This is as stated by Walton H. Hamilton, that Constitutionalism is the name given to the beliefs uttered by people with power which are then passed on to parchment to maintain order in government. ${ }^{4}$

Although this concept is outdated, constitutionalism is still the most effective understanding for managing power in modern times today. As said by contemporary political thinker Gabriel A. Almond, who states that the best form of government that can be realized is a mixed government or constitutional government, which limits freedom by the rule of law and also limits people's sovereignty with state institutions that produce order and stability. ${ }^{5}$ So, constitutionalism presents a situation that can foster a sense of security, because there are restrictions on the authority of the government that have been determined in advance.

Based on the above background, the main problem in writing this paper is how is the essence of the concept of constitutionalism in the administration of the state in the aspect of the constitutional system? The purpose of this paper is to find out the essence of the concept of constitutionalism in the administration of the state in the aspects of the constitutional system of the republic of Indonesia.

\section{Discussion}

\subsection{The Doctrine of Constitutionalism in Development ${ }^{6}$}

Literally "constitutionalism" is defined as an understanding of government according to the constitution or briefly called a constitutional state. In the scientific world of this understanding, the doctrine has developed from the classical doctrine, including:

\subsubsection{Doctrine of Classical Constitutionalism}

Colored by three different understandings due to the different philosophies of each era, including: Ancient Greece Era and Ancient Roman Age

Ancient Greece Era. Based on the philosophy of freedom, according to the understanding of Ancient Greece, "constitutionalism" is a polis (city state) whose government is based on the principle of direct democracy. The polis as the embodiment of the "constitution" regulates all the needs of the people, both material and spiritual. Theoretically the Ancient Greek understanding of "constitutionalism" was strengthened by the opinions of Plato and Aristotle (Philosophers in Ancient Greece). For Plato and Aristotle, a good citizen is measured by his obedience to the constitution and laws. In his explanation of the ideal constitution, both Plato and Aristotle emphasized the importance of political/civic education, because through stateeducated citizens, they would avoid anarchic actions.

It can be added that according to Aristotle politea or constitution is higher than nomoi or law. Because the constitution has the power to form rules or create norms, while

\footnotetext{
${ }^{4}$ Walton H. Hamilton. (1931). “Constitutionalism”. New York: Macmillian, p. 255.

${ }^{5}$ Excerpted from the writings of Gabriel A. Almond. (1996). "Political Science: The History of the Discipline", in Robert E. Goodin and Hans-Dieter Klingemann (eds), A New Handbook of Political Science, Oxford: Oxford University Press, p. 53-61.

${ }^{6}$ Atmadja. (2012). Hukum Konstitusi Problematika Konstitusi Indonesia Sesudah Perubahan UUD 1945. Malang: Setara Press, 2012, p. 13-20
} 
the law must be form in accordance with the constitution so that the contents systematic.

Ancient Roman Age. Based on empirical philosophy that Understanding his against constitutionalism with regard to the existence of the constitution, is seen as an instrument of government, in the form of: public habits, lawyers' records, statesman's records, people's beliefs and beliefs related to the existence of the constitution.an with the method or method of administering state power. So basically Roman Constitutionalism, in the form of a really positive constitution as an instrument of government which can be in the form of a president in society, records of lawyers and statesmen, beliefs, public trust is used as a way of holding state power.

In the understanding of Roman constitutionalism there are three elements of government that share power and have a balanced power so that they control each other (checks and balances), namely: first, monarchy (handed over from the king's hand), which is manifested in the position of advisor.. There are two advisory positions and are elected every year, each of which has the right to veto the other. The second element is the aristocratic element, which is manifested in the form of the senate, an assembly that has great legislative power. The third element is the democratic element, in the form of people's meetings in three types of conventions, namely based on land or territory, people, and ethnicity.

There seems to be a difference in understanding of constitutionalism between the Greeks and the Romans. The Greek (Ancient) perception was idealistic, while the Roman (Ancient) conception of constitutionalism had a perception of the constitution as an instrument of government, so it was instrumental.

\subsubsection{Doctrine of Constitutionalism Medieval}

Colored and influenced by the philosophy of fiudum, that is understanding of constitutionalism that described as feudalism, a form of government ruled by feudal lords or landlords.

In more detail, it can be stated that feudalism, which is one of the medieval type of constitutionalism. Characteristic main:

- Country become divided into small units under the power of the landlords

- Hierarchy power is centered on the Emperor who oversees para baron-baron (landlord aristocrats) who control the people (farm workers or cultivators)

- The Emperor's prerogatives were born, which are influential to this day, in the fields of justice such as pardons, amnesty, abolition, and rehabilitation.

Phenomenon medieval constitutionalism very fast growing because of phenomenon of feudalism which is medieval constitutionalism with features main is the division of land tenure in the empire's territory into small units, the general principle was that every group of people was under the rule of the landlord. In relation to this feudalism, the Emperor as the pinnacle of power was seen as having real control over the lands called the Baron. In practice the Emperor is only a symbol, while in real the supremacy of power is in the hands of the Baron.

The collapse of feudalism was caused by the insistence of the spirit nationalism and freedom and widespread democracy in Europe marked a modern era in history, in particular on the development of understanding of the understanding of constitutionalism. 


\subsubsection{Modern Constitutionalism Doctrine}

Based on the philosophy of nationality, freedom and equality, sparked by the American revolution and the French revolution, various views on the doctrine of modern constitutionalism were born, which is essentially "government based on the constitution", with the main characteristics: Restrictions government power; Government which is not arbitrary; and Government responsible and accountable to the people.

Some opinions that can be said to have an influence on the understanding of constitutionalism is that At first, constitutionalism was described as the division of power and the separation of powers according to the Triassic theory politics from Montisquieu, that state power is separated from power the legislature serves to make laws, executive power that functions to carry out the law, and judicial power that function to prosecute violations of the law. Too aim for prevent government absolute and authoritarian to create trust and agreement between citizens and the government.

That consensus or agreement cover Agreement on goals and acceptance of state philosophy, Agreement on the rule of law as the basis for governance, and Agreement on form-forms of institutions and administrative procedure. The three agreements will also guarantee the establishment of constitutionalism.

If the general agreement collapses, then the legitimacy of the state's power will also collapse, and in the end, turn happens civil War or revolution. This, for example, is reflected in three important historical revolutionary events that have been experienced in Europe and America, namely: the French Revolution (1789), the American Revolution (1776), and the Russian Revolution (1917). Likewise, Indonesia carried out a revolution, through the Proclamation of Independence on August 17, 1945, giving birth to the Republic of Indonesia with the 1945 Constitution, which Ir. Soekarno called the Revolutionary Constitution.

For the Indonesian state of the three elements, the most decisive is the consensus regarding the position of the Preamble to the 1945 Constitution which is the consensus of Indonesian independence. That means, the Preamble to the 1945 Constitution determines the existence of the Republic of Indonesia on the basis of the Pancasila state.

\subsection{The Essence of the Concept of Constitutionalism}

\subsubsection{There are Power Limitations}

Although the notion of constitutionalism is derived from the constitution, and in its development it even encourages the existence of a Constitutional State, the essence of constitutionalism is in initiating the limitation of power in the state. This can be seen from the arguments put forward by Michael Allen and Brian Thompson that the principle of constitutionalism rests on the idea of limiting the government in exercising its power. Therefore, Constitutionalism must be regulated in order to prevent arbitrary power. ${ }^{7}$ The same opinion was also emphasized by Carl J. Frederich that

\footnotetext{
${ }^{7}$ Michael Allen and Brian Thompson. (2002). 7th Edition, Cases \& Materials on Constitutional \& Administrative Law. London: Oxford University Press, p. 14.
} 
constitutionalism is an institutional system of effective and regular restrictions on actions taken by the government. ${ }^{8}$ This opinion actually refers to the basic concept that constitutionalism in a general sense is a complex idea, attitude, and pattern of behavior that outlines the principle that government authority originates and is limited by basic law (Fundamental Law). ${ }^{9}$

Thus, the notion of constitutionalism contains the essence of limiting power and power itself is limited by the constitution as the highest legal norm. The issue that is considered the most important in constitutional understanding is the regulation regarding supervision or limitation of government power. The notion of Constitutionalism carries a limitation of power, so that the administration of the state and government is not arbitrary and this matter is stated and regulated explicitly in the articles of the constitution. In this regard Andrew Vincent asserts that the constitution has placed a major emphasis on limiting and diversifying authority and power. ${ }^{10}$ Therefore, in essence, modern constitutionalism actually concerns the principle of limiting power or what is commonly referred to as the principle of limited government. That is, in the understanding of constitutionalism, the power to prohibit and procedures are determined, so that the government's power guarantees a government that is not arbitrary and a responsible government. The idea of regulating and limiting this power naturally arises because of the need to respond to the development of the relative role of general power in the life of the state and society.

\subsubsection{Based on General Agreement (Consensus)}

The notion of constitutionalism is essentially based on the existence of a general agreement (consensus) among the majority of the people regarding the ideal building with respect to the state. This statement is based on the fact that state organizations are needed by citizens so that their common interests can be protected or promoted through the formation of the so-called state, as emphasized by William George Andrews that members of the political community have, by definition, common interests that they seek to be promoted or protected through the use of a mandatory political mechanism which we call the State. ${ }^{11}$ So the key words of consensus or general agreement are the general goals of society or the general acceptance of the same philosophy of government, the rule of law on which the government is based, and reforms and institutional procedures. ${ }^{12}$

These three elements determine the establishment of constitutionalism in a country. According to Jimly Asshiddiqie, if the general agreement collapses, the legitimacy of the state's power will also collapse, and in turn civil war or revolution can occur. ${ }^{13}$ This is, for example, reflected in three major events in the history of mankind, namely the important revolutions that occurred in France in 1789, in America in 1776, and in

\footnotetext{
${ }^{8}$ Carl J. Frederich. (1963). Man and His Government. New York: McGraw-Hill, p. 217.

${ }^{9}$ Andrew Vincent. (1987). Theories of The State. New York: Basil Blackwell Inc., p. 91.

${ }^{10}$ Don E. Fehrenbacher. (1989). Constitutions and Constitutionalism in the Slaveholding South. Georgia: University of Georgia Press, p. 1

${ }^{11}$ William George Andrews. (1968). Constitutions and Constitutionalism, 3rd ed. New Jersey: Van Nostrand Company, p. 9.

${ }^{12}$ Ibid., p. 12-13.

${ }^{13} \mathrm{Jimly}$ Asshiddiqie, Konstitusi dan...op.cit., p. 21.
} 
Russia in 1917, or in Indonesia in 1998, as well as the most recent revolution that occurred in the United States. Iraq in 2008 and in Egypt in 2013. All of these were caused because among citizens there was no consensus regarding the ideal state building. Furthermore, Jimly also said that with the agreement, the constitution can be easily formulated because it truly reflects a common desire regarding state institutions and state administration mechanisms to be developed within the framework of a constitutional state. ${ }^{14}$

With such a framework, the constitution in the understanding of constitutionalism is ultimately understood as the highest law because it is the highest form of social agreement of all sovereign people in a country through a public deliberation. In the constitution there are various legal, political and economic documents that function as tools that provide guidelines, directions, and instructions for a country to organize itself, as a result of a compromise of various powers when the constitution was formulated and formed. This is in line with KC Wheare's opinion, that the constitution is indeed the result of the political, economic, and social forces operating at the time of adoption. ${ }^{15}$

\subsubsection{As Integral to Democratic Governance}

The notion of constitutionalism is an integral component of a democratic government. Without imposing constitutionalism on him, democratic government is impossible. Therefore, a democratic state must implement and carry out constitutionalism in the soul of its nation so that a democratic government can be realized. Such an argument is based on a principle that democratic government can only be created when the concept of democracy that is built is the concept of democracy based on law or constitutional democracy. According to Miriam Budiarjo, the hallmark of constitutional democracy is the idea that a democratic government is a government that has limited powers and is not allowed to act arbitrarily against its citizens. ${ }^{16}$

Thus, the feature of democratic government is that government actions must always be based on the will of the constitution as the essence of constitutionalism. The idealized democracy must be placed in the corridor of law. Without law, democracy can actually develop in the wrong direction because the law can be interpreted unilaterally by the authorities in the name of democracy. On this side, the notion of constitutionalism positions the constitution as an integral component of democratic government.

2.2.4. Wants the Execution of Power to be Accountable.

In the understanding of constitutionalism, accountability for the exercise of power is a constitutional necessity as that power is obtained and the scope of that power is used. In the power-sharing system there is a principle that every power must be accounted for.

So in a system of government that is formed based on the will of the majority of the political community, it requires that the government is responsible for the actions of the majority. So that no one can exercise authority without assuming obligations and

\footnotetext{
${ }^{14}$ Ibid., p. 23.

${ }^{15}$ KC Wheare, Modern Constitution. (1966). Second Edition. London, New York: Oxford University Press, p. 67.

${ }^{16}$ Miriam Budiardjo, op.cit., p. 107.
} 
responsibilities or without carrying out supervision. According to Ridwan HR., in the perspective of public law, the existence of this authority gives rise to a system of accountability, in line with the general principle that there is no authority without accountability. ${ }^{17}$

With this meaning, the constitution itself becomes the scope of responsibility that binds the authorities for all forms of the use of power. In other words, the use of power by officials within state institutions must be held accountable in accordance with what is mandated in the constitution. Therefore, the understanding of constitutionalism clearly requires the implementation of these powers to be accounted for, so that in the power-sharing system the principle applies that every power must be accounted for.

\section{Closing}

Constitutionalism for modern countries as a necessity. Constitutionalism is still the most effective understanding for managing power in modern times today. In the understanding of constitutionalism, the constitution is the embodiment of the highest law that must be obeyed by all components of the state. The existence of a constitution for a country is essentially the root of constitutionalism which is not only intended to limit the authority of the ruler, guarantee the rights of the people and regulate government, but the constitution is also a tool for the people to consolidate political and legal positions by regulating life together to achieve goals.

In a philosophical sense, constitutionalism requires a limitation of power in the state, which is based on a general agreement (consensus) among the majority of the people regarding the idealized building with respect to the state. Constitutionalism is an integral component of democratic governance. Without imposing constitutionalism on him, democratic government is impossible. In addition, the notion of constitutionalism requires that the exercise of power be accounted for within the limits required by the constitution.

\section{References}

Journal:

[1] Evy Yuliati and Widayati, "Public Services in Election of Regional Chairman", in Law Development Journal Vol 3 No 1, http://jurnal.unissula.ac.id/index.php/ldj/article/view/14233

Books:

[1] Andrew Vincent. (1987). Theories of The State. New York: Basil Blackwell Inc

[2] Atmadja. (2012). Hukum Konstitusi Problematika Konstitusi Indonesia Sesudah Perubahan UUD 1945. Malang: Setara Press, 2012

[3] Carl J. Frederich. (1963). Man and His Government. New York: McGraw-Hill

[4] Don E. Fehrenbacher. (1989). Constitutions and Constitutionalism in the Slaveholding South. Georgia: University of Georgia Press

\footnotetext{
${ }^{17}$ Ridwan HR. (2007). Hukum Administrasi Negara. Jakarta: RajaGrafindo Persada, p. 352.
} 
[5] Excerpted from the writings of Gabriel A. Almond. (1996). "Political Science: The History of the Discipline", in Robert E. Goodin and Hans-Dieter Klingemann (eds), A New Handbook of Political Science, Oxford: Oxford University Press.

[6] KC Wheare, Modern Constitution. (1966). Second Edition. London, New York: Oxford University Press

[7] Michael Allen and Brian Thompson. (2002). $7^{\text {th }}$ Edition, Cases \& Materials on Constitutional \& Administrative Law. London: Oxford University Press

[8] Miriam Budiardjo. (2008). "Dasar-Dasar Ilmu Politik, Edisi Revisi". Jakarta: Gramedia Pustaka Utama

[9] Richard Samuelson. (2003). "John Adams and the Republic of Law". Maryland: Lexington Books

[10] Ridwan HR. (2007). Hukum Administrasi Negara. Jakarta: RajaGrafindo Persada

[11] Walton H. Hamilton. (1931). "Constitutionalism". New York: Macmillian

[12] William George Andrews. (1968). Constitutions and Constitutionalism, 3rd ed. New Jersey: Van Nostrand Company 